\title{
Is Consumer Self-Confidence Intervenes the Relationship between Shopping Motives and Search for Dress Information?
}

\author{
Abdelhalim Issa Al-Zu'bi ${ }^{1}$ \\ ${ }^{1}$ Al-Balqa' Applied University, Business School, Marketing Department, Alsalt, Jordan \\ Correspondence: Abdelhalim Issa Al-Zu'bi, Al-Balqa' Applied University, Business School, Marketing \\ Department, Alsalt, Jordan. E-mail: drabdoissazoubi@yahoo.com
}

Received: August 5, 2015

Accepted: August 24, 2015 Online Published: September 29, 2015

doi:10.5539/ijms.v7n5p94

URL: http://dx.doi.org/10.5539/ijms.v7n5p94

\begin{abstract}
The main purpose of this study is to examine the relative influence of utilitarian, recreational, and socialization motives on Jordanian young consumers search for dress information using self-confidence as an intervention variable. Based on a random sampling technique, the self-administered questionnaire was used to solicit the responses of graduate and undergraduate college students ranging in age from 18 to 24 years. The principal component analysis using varimax rotation method and confirmatory factor analysis were used to validate the research model. Multiple regression analysis using Structural Equation Modeling and bootstrapping analyzes in AMOS 7 were used to examine the direct and indirect influences of shopping motives whilst the Independent-Sample $T$ test and One-Way ANOVA techniques were conducted to measure the variability of model's variables across subjects' gender and an annual income. Principally, results indicate that the unique contribution of the total influence on consumer self-confidence is associated with utilitarian motives while the recreational motives scored the highest total impacts on searching for dress information. The consumer self-confidence and recreational motives have positively scored the highest direct influences on searching for dress information while the highest intervening influence is connected with utilitarian motives. However, this study enriches the existing literature with new findings related to consumers' motives within the context of collectivist culture. In terms of marketing implications, limitations, and recommendations for future research were also discussed.
\end{abstract}

Keywords: young consumers, shopping motives, self-confidence, search for information, consumer socialization behavior, collectivist culture, structural equation modeling, Jordan

\section{Introduction}

Past research has elucidated that the determinants of consumer behavior including motives are differed across shopping, buying, and consuming activities (Sheth, 1983; Tauber, 1972) that are influenced by the early stages of individual's life (Moschis, 1987). Shopping motivation is defined as "the drivers of behavior that bring consumers to the marketplace to satisfy their internal needs" (Jin \& Kim, 2003, p. 399). These drivers are not always based on a rational process (Buttle, 1992; Lim \& Ang, 2008), and influenced by consumers experiences and satisfaction (Westbrook \& Black, 1985). In that, a number of scholars have pointed out that consumers are prompted to go shopping for utilitarian, recreational, and social reasons (e.g., Babin, Darden, \& Griffin, 1994; Davis, Peyrefitte, \& Hodges, 2012; Dawson, Bloch, \& Ridgway, 1990; Hyun-Mee \& Miller, 2007; Jin \& Kim, 2003) that are profoundly fluctuated across the types of products. For instance, there is no similarity between consumer shopping motives for buying gifts and grocery products (Dholakia, 1999) whereas consumer self-expression, fantasy, and recreational shopping have been associated with buying clothes products (Buttle, 1992). Moreover, consumer search for information regarding products and services precedes the consumers' choice behavior (Solomon, Bamossy, \& Askegaard, 1999) that comprising internal and external information search. An internal information search portrays retrieval information from memory storage that occurring prior to external information, facilitating the acquisition of new information, and increasing search efficiency. In contrast, an external information search refers to everything related to market environment stimuli such as advertising and word of mouth (Brucks, 1985). Search for information is differed by gender and type of products. Males analyze information less intensely than females because females are less independent and assertive and gratify interpersonal relations more than males (Barber, Dodd, \& Kolyesnikova, 2009). Danesi (2004, p. 179) 
defines clothing product as "signs extending the basic meaning of bodies in a cultural context". On the contrary, dress incorporating a spectrum of accessories is referred to "any intentional modification of appearance" (Damhorst, Miller, \& Michelman, 2005, p. 2). However, the dress term in this study refers to clothing and shoes.

Further, the marketing literature affirms the importance of consumer self-confidence, as a psychological variable, in explaining consumers' decisions and behaviors (Bearden, Hardesty, \& Rose, 2001; Lysonski \& Durvasula, 2013; Park, Mothersbaugh, \& Feick, 1994; Sheth, 1983). Specifically, Bearden et al. (2001) classified the concept of consumer self-confidence into six distinctive dimensions. For example, they referred information acquisition to a consumer's confidence in his/her ability to collect product information prior to making a purchase decision. Personal and social confidence manifest consumer ability to make decisions that gratify his/her personal goals and produce positive outcomes as a result of interactions with others. Consumer self-confidence is not restricted to specific product or service categories (Bearden et al., 2001) portraying the consumers' tendency rather than the real competence of consumers (Hellén \& Sääksjärvi, 2011). Hence, the potentiality of market segmentation is increased by the identification of consumer self-confidence (Bearden et al., 2001) and shopping motives (Babin et al., 1994).

Culturally, the diversity of cultural orientations determines clothing consumption behavior across different societies (Bakirtas, Bakirtas, \& Cetin, 2015) since the social groups in a collectivist societies are more likely to guide the purchases decision of its members (Kalliny, Saran, Ghanem, \& Fisher, 2011). In terms of cultural values, individuals of collectivistic cultures are more apt to trust in-groups' members than out-groups' members resultant to the nurturance processes (Triandis, 2001). Therefore, Jordanian community like other Eastern societies relies on in-group interactions (Shoup, 2007).

However, a dearth research has been investigated the divergence of consumer self-confidence and shopping motives across cultures' orientations (e.g., Chelminski \& Coulter, 2007; Davis et al., 2012). Similarly, shopping motives (Chang, Burns, \& Francis, 2004; Chen-Yu \& 2002; Dholakia, 1999; Workman \& Cho, 2012) and self-confidence (Barber et al., 2009; Bearden et al., 2001; Dawson et al., 1990) were markedly differed across the socio-economic variables.

Departing from the aforementioned perspectives, it is important to note that while a scant research has predominantly focused on the relationship between shopping motives and self-confidence, unfortunately, no single study has explicitly examined the mediation effects of self-confidence on the relationship between shopping motives and search for dress information. To fill this gap, research in hand aims to address the following objectives:

- Investigate the relative influence of utilitarian, recreational, and socialization motives on young consumers search for dress information using self-confidence as an intervening variable.

- Scrutinize the dimensions of young Jordanian shopping motives for not being validated within the realm of collectivist culture. There is no construct of shopping motives can be used across different countries (Geuens, Brengman, \& Jegers, 2001).

- Measure the variability of model's dimensions across gender and annual income variables.

\section{Literature Review and Hypotheses}

\subsection{Social Motivation}

Shoppers behavior is influenced by social shopping motives (Arnold \& Reynolds, 2003). Previous research has demonstrated consumer socialization as a lifelong process in which individuals acquire consumer skills, knowledge, and attitudes as a result of social interactions (John, 1999; Moschis, 1987). Therefore, the patterns of consumption preferences, attitudes, and behaviors are transferred from one generation to the next (John, 1999; Minahan \& Huddleston, 2010; Moore, Wilkie, \& Lutz, 2002; Moschis, 1987). The social groups played vital roles in steering consumers' values, attitudes, and behaviors (Sheth, 1983). Accordingly, there are two types of informational sources including personal and impersonal. While the personal sources refer to parent, friend, and salespeople (Hyun-Mee \& Miller, 2007; Westbrook \& Black, 1985), impersonal information sources represent sales promotions, store displays, and observing other people (Kinley, Josiam, \& Lockett, 2010). Interaction with personal or impersonal agents provides shoppers with an opportunity to get information on products and assists them to get more reasonable prices (Hyun-Mee \& Miller, 2007; Tauber, 1972; Westbrook \& Black, 1985). Specifically, the social interactions among consumers accounted $25 \%$ of total interactions of the shopping malls (Feinberg, Sheffler, Meoli, \& Rummel, 1989) while $81 \%$ of American's family clothing purchases and 52\% of car choices were influenced by young people of ages ranging from 13 to 21 year olds (O'Donnell, 2006). In that essence, the American daughters described shopping with their mothers as a "nice activity" while mothers and 
daughters revealed mutual influences during the shopping activity. Young women aged between 20 and 22 trust their mothers in gaining the skills of shopping as a result of consumer socialization and the time spent with their mother in shopping (Minahan \& Huddleston, 2010). Jin and Kim (2003) found that the Korean discount shoppers have scored the highest grades on the dimension of social shopping motive. They enjoyed on shopping trips by being in a crowd through identifying their level of accomplishment compared to other shoppers. The Chinese consumers are frequently going to shop with friends or family members for product advice and to help them in bargaining the prices of products (Davis et al., 2012) and the high school adolescents as a source for apparel information are more influenced by friends (Chen-Yu \& Seock, 2002).

Moreover, gender plays a significant role in consumer socialization (John, 1999), and personal sources of information are the most important for females whilst males rely on published material (Barber et al., 2009). The similarity was also found between males and females with respect to adolescents' clothing shopping behavior, and friends had represented the most important clothing information source for both males and females (Chen-Yu \& Seock, 2002). In contrast, the effect of interacting with family as a motive is not significantly differed across gender while the pleasure of shopping with others is greater for males (Dholakia, 1999).

Extrapolating from the above literature, the following hypotheses were proposed:

H1: The socialization motives positively influence the self-confidence of Jordanian young consumers.

$\mathrm{H} 2$ : Search for dress information is influenced by the socialization motives of Jordanian young consumers.

H3: The socialization motives of Jordanian young consumers are not differed across gender and an annual income.

H4: Jordanian young consumers' search for dress information is not differed by gender and an annual income.

\subsection{Utilitarian Motivation}

Utilitarian motives allure consumers to focus on the rationality of task-completion and the peculiarities of product functions (Babin et al., 1994; Bellenger \& Korgaonkar, 1980; Lim \& Ang, 2008) including price competitiveness and the quality of products (Chen-Yu \& Seock, 2002; Westbrook \& Black, 1985; Workman \& Cho, 2012). Hence, the utilitarian shoppers are less engaged in information search, nonplanned purchases, spend less time shopping per trip (Bellenger \& Korgaonker, 1980), and emphasized on sales prices, low prices and product return policies (Shim \& Kotsiopulos, 1992).

Culturally, Westbrook and Black (1985) referred the negotiation motives to bargain hunting that prevalent the markets of collectivist cultures (i.e., Middle East and Eastern societies). Chinese consumers are more likely to be motivated to go shopping for utilitarian purposes since they save time and energy in accessing information (Cai \& Shannon, 2012; Tsao \& Tsao, 2013), rely heavily on store prices (Davis et al., 2012), and have more tendencies towards promotion of utilitarian products (Lim \& Ang, 2008). Equally, Korean discount shoppers are more likely to be utilitarian shoppers (Jin \& Kim, 2003). With regard to Turkish and British consumers, the utilitarian motives reveal high variation in brand equity whereas brand association does not significantly influence the utilitarian consumption behavior. Overall, Turkish and British consumers were not differed in utilitarian consumer behavior (Cal \& Adams, 2014). Within the contextualization of Arab shopping behavior, purchasing clothes are connected with the bargain hunting motive whereas planning purchasing and performing multiple tasks are not associated with the convenience motive (Farrag, El Sayed, \& Belk, 2010). Tunisian shoppers are more likely to be influenced by the stores' prices, services quality, and the closeness of stores to their homes (Mejri, Debabi, \& Nasraoui, 2012).

In terms of demographic variables, shopping motives were significantly influenced by the consumers' sex with respect to the utilitarian motive. Males view utilitarian motives are less important than women and most males assume primary responsibility for purchasing their clothes (Dholakia, 1999). Males demonstrate greater utilitarian motives for clothing shopping (Chang et al., 2004) and the product motives are positively related to age and females scored the highest grade on product motives (Dawson et al., 1990). Males are more influenced by the quality of a product than females whilst females perceived product price as more important than males (Bexley, 2014).

However, the above findings lead to proposing the following hypotheses:

H5: Utilitarian motives positively influence the self-confidence of Jordanian young consumers.

H6: Search for dress information is negatively influenced by the utilitarian motives of Jordanian young consumers.

H7: Utilitarian motives of Jordanian young consumers are not varied by gender and an annual income. 


\subsection{Recreational Motivation}

Recreational shopping has been broadly defined as "shopping activity that is characterized by the shopper experiencing intrinsic rewards from the shopping process per se, either in conjunction with, or independent of, the acquisition of goods and services" (Guiry, Magi, \& Lutz, 2006, p. 75). Using a combination of qualitative and quantitative approaches, Arnold and Reynolds (2003) have identified six hedonic shopping motives including adventure, gratification, role, value, social, and idea shopping motives. Gratification motive stresses consumers' relaxation and enjoyment whereas value-shopping dimension is related to sales, discounts, and bargains. Idea shopping motivation urges shoppers to keep up with new trends related to products and fashions. Therefore, recreational shopping implies consumer's fantasy, freedom, entertainment, loyalty, spending more time on shopping trips, seeking for information, visiting various stores, continuing to shop after making a purchase and searching for a variety of products (Babin et al., 1994; Bellenger \& Korgaonkar, 1980). According to Dawson et al.'s (1990) findings, the diversity of products and prices have positively and highly explained the variability of the purchase outcomes whilst experiential motives are negatively related to purchasing.

Within the realm of collectivist culture, the hedonic motives of Egyptian consumers reflect entertainment, freedom, appreciation of modernity, and self-identity (Farrag et al., 2010) while the Singaporean consumers prefer hedonic products more than utilitarian products compared to Chinese consumers in Shanghai (Lim \& Ang, 2008). Jin, Sternquist, and Koh (2003) found that the sale proneness negatively associated with hedonic clothes shopping whereas the positive relationship was found between Korean hedonism and price mavenism, and value consciousness. The hedonic value of Turkish clothing shoppers has a greater influence on both consumer satisfaction and behavioral intentions than the utilitarian value (Bakirtas et al., 2015).

In relation to demographic variables, females are more likely to be recreational shoppers (Arnold \& Reynolds, 2003; Chang et al., 2004; Bellenger \& Korgaonker 1980) and have more tendencies to shop for recreation than males in buying clothes (Chen-Yu \& Seock, 2002). The relationship between participants' sex and product motives was found; female shoppers scored the highest tendency on product motives whereas experiential motives "see new things and watch other people" are the highest among males' shoppers (Dawson et al., 1990).

In light of these findings, the following hypotheses were proposed:

H8: Recreational motives positively influence the self-confidence of Jordanian young consumers.

H9: Search for dress information is positively influenced by recreational motives of Jordanian's young consumers.

H10: Recreational motives of Jordanian young consumers are not differed by gender and an annual income.

\subsection{Self-Confidence}

Consumer self-confidence is an unstable phenomenon (Hellén \& Sääksjärvi, 2011), and recognized as a fundamental concept to understand the consumer behavior (Bearden et al., 2001; Lysonski \& Durvasula, 2013; Park et al., 1994). In 1969, Howard and Sheth suggested that there is a direct relationship between overall confidence and behavioral intention. Bennet and Harrell (1975) confirmed Howard and Sheth's argument through investigating the connection between buyers' confidence and their purchase attitudes and intentions towards products brands. Similarly, the frequency of consumers' engagement in shopping activities empowers them to have product knowledge and experiences (Lysonski \& Durvasula, 2013), therefore, self-confidence has been used as an antecedent variable to internal product knowledge (Barber et al., 2009; Bearden et al., 2001). Nonetheless, Bearden et al. (2001) have referred the concept of self-confidence to the level of consumers' feelings about their abilities and certainty when they engaged in shopping activities regardless of the types of products and services. They have validated the construct of consumer self-confidence to incorporate six distinctive dimensions including information acquisition and processing, consideration set formation, personal and social outcomes, persuasion knowledge, and marketplace interfaces. Clearly, personal confidence and social confidence refer to consumer ability to make decisions that gratify the personal goals and produce positive results in the form of the reactions of others. Information acquisition refers to consumer confidence to act efficiently in market milieu through obtaining and understanding that information adequately (Bearden et al., 2001). Accordingly, consumer with high self-confidence is more proneness to discuss their consumption knowledge with others (Bearden et al., 2001) since the relationship between consumer self-confidence and product expertise is positively correlated (Teichmann, 2011). As a source of information, consumers with high levels of purchase confidence are more likely to rely on their ability while consumers of low purchase confidence frequently depend on friends (Barber et al., 2009). Moreover, the individuals' shopping experiences are more associated with social confidence and personal confidence (Paridon, 2008), as a result, consumer social 
confidence are more likely to susceptible to normative influences (Bearden et al., 2001) and moderates the influence of hedonic and utilitarian values on information sharing behavior (Paridon, 2006).

Additionally, consumer self- confidence differs across individualistic and collectivistic cultures. For instance, the South Korean consumer's self-confidence is a stronger predictor for market mavens than American consumers (Chelminski \& Coulter, 2007). About the demographic variables, females have somewhat greater confidence in social outcomes and consideration-set formation than males (Bearden, Hardesty, \& Rose, 2001). In contrast, the higher self-confidence in men was associated with age and the relationship was found between the high level of self-confidence, higher income in men and greater occupational complexity among women (Adelmann, 1987).

Based on the literature cited above, the following hypotheses are proposed:

H11: The consumer self-confidence positively mediates the influence of socialization motives on searching for dress information.

H12: The consumer self-confidence positively mediates the influence of utilitarian motives on searching for dress information.

H13: The consumer self-confidence positively mediates the influence of recreational motives on searching for dress information.

H14: The consumer self-confidence of Jordanian young consumers is not differed across gender and an annual income.

\section{Method}

\subsection{Sampling and Data Collection}

The target population consists of all consumers aged from 18 to 24 years old while the sampling frame encompasses graduate and undergraduate college students enrolling in Jordanian academic institutions. Dependent on a random sampling technique, three universities out of ten covering the midst region were randomly chosen to recruit the sample elements. Further, the self-administered questionnaire was employed, and the translation of questionnaire's statements from English to Arabic and backward translations were carried out prior to data collection since the questionnaire was in the Arabic language. The questionnaire has involved three sections; the first section contains 14 statements related to shopping motives and dress items whereas the five statements of second section mirror the self-confidence. The final section is proposed to collect the factual data such as gender, age, marital status, and annual income. The data collection process was accomplished over a period of 6 weeks in 2013, and the subjects were voluntarily participated in the survey. In total, 320 questionnaires were distributed and collected in classroom settings, and 36 questionnaires were dropped from the consecutive analysis resulting in 284 useable responses since some questions were left blank or checked with two or more answers.

\subsection{Measurement and Validity}

\subsubsection{Independent Variables}

The construct of shopping motives is operationalized as the relative influence of utilitarian, recreational, and socialization motives that impelling Jordanian young consumers to search for dress information. Specifically, 12 Likert-type items ranging from strongly disagree (1) to strongly agree (5) were adapted from previous research (Arnold \& Reynolds, 2003; Babin et al., 1994) to measure the shopping motives. Prior to ascertaining the latent variables, the results of sample adequacy and Bartlett's test have supported the appropriateness of the observed data to the factor analysis $\left(\mathrm{KMO}=.680 ; \chi^{2}=688.567, \mathrm{df}=66, \mathrm{p}=.000\right)$. Principal component factor analysis-varimax rotation is typically used to confirm the internal validity of construct (Churchill, 1979), however, Table 1 shows that the proposed items were loaded into three interpretable factors that jointly explained $51.569 \%$ of the total variance. Utilitarian, socialization, and recreational motives were respectively explained $24.288 \%, 14.510 \%$, and $12.771 \%$ of the total variance, and Cronbach's alpha for all factors were above (.60). Further, Confirmatory Factor Analysis (CFA) was conducted to substantiate the multi-dimensionality of shopping motives construct through using AMOS 7.0. The fit indices of (CFA) have suggested that the underlying dimensions of shopping motives represent a reasonably good fit to the observed data $\left(\chi^{2}=102.280, \mathrm{df}=52, \mathrm{CMIN} / \mathrm{DF}=1.967<3, \mathrm{GFI}=.943, \mathrm{AGFI}=.915, \mathrm{NFI}=.853, \mathrm{CFI}=.920, \mathrm{TLI}=.899\right.$, RMSEA $=.058)$. RMSEA's value ranging from $(.05)$ to $(.08)$ shows a good fit to the sample data (MacCallum, Browne, \& Sugawara, 1996). According to Hair, Black, Babin, and Tatham's (2006) recommendations, the composite reliability for all factors has surpassed the threshold score (.70) whilst the Average Variance Extracted (AVE) are greater than $(0.50)$ as the minimum value exclusive utilitarian motives scale. In addition, the value of 
Average Variance Extracted (AVE) for each construct is greater than its squared correlation coefficients with other latent variables thus the discriminant validity is justified (Anderson \& Gerbing, 1988). Albeit the AVE value of utilitarian motives does not exceed the threshold coefficient (0.50) as proposed by Hair et al. (2006), AVE value is very often less than fifty percent (Hatcher, 1994), however, the composite reliability $\geq(.60)$ and item loadings $\geq(.50)$ confirm the convergent validity (Bagozzi \& Yi, 1988).

\subsubsection{Intervening and Dependent Variables}

The construct of self-confidence is conceptualized in line with Bearden et al.'s (2001) definition. Five items were borrowed from Bearden et al. (2001) and measured on a 5-point Likert-scale $(5=$ strongly agree; $1=$ strongly disagree). The principal component factor analysis has extracted one factor only explaining (41.063\%) of the total variance whereas KMO $(0.746)$ and Bartlett test of sphericity $\left(\chi^{2}=148.129\right.$, df $\left.=10, p=.000\right)$ confirmed the suitability of using factor analysis. Thus, the unidimensionality of construct was supported while the internal reliability of construct (Cronbach's alpha $=.65$ ) showed an adequate internal consistency (Bagozzi \& Yi, 1988).

Table 1. Means, standardized deviations, and factor loadings

\begin{tabular}{|c|c|c|c|}
\hline Model Variables & Mean & $\mathrm{M}(\mathrm{SD})$ & Factor Loading \\
\hline (V2) I am able to choose the right dress for most occasions. & 3.806 & .933 & .490 \\
\hline (V3) I can tell which brands meet my expectations. & 3.620 & 1.088 & .400 \\
\hline (V9) I know where to look to find the product information I need. & 4.032 & .929 & .570 \\
\hline (V10) I often have no doubts about the purchase decisions I make. & 3.870 & 1.086 & .560 \\
\hline (V13) My friends are impressed with my ability to make satisfying purchases. & 3.514 & 1.123 & .380 \\
\hline Summated Self-Confidence Items & 18.841 & 3.300 & - \\
\hline I was able to do a lot of fantasizing during the shopping trips. & 3.377 & 1.198 & .603 \\
\hline Shopping trip for dress is truly a joy. & 3.940 & 1.245 & .820 \\
\hline Shopping is one of my favorite leisure activities. & 3.891 & 1.255 & .851 \\
\hline Summated Recreational Shopping Motivation Items & 11.208 & 2.852 & - \\
\hline Buy one-get one free drives me to buy the dress. & 4.352 & .816 & .653 \\
\hline The diversity of store's products drives me to buy the dress. & 4.215 & .869 & .684 \\
\hline For the most part, I go shopping for dress when there are sales. & 4.144 & .938 & .694 \\
\hline I accomplished just what I wanted to on specific shopping trip. & 3.912 & 1.044 & .536 \\
\hline I enjoy hunting for bargains when I shop for dress. & 4.067 & .994 & .669 \\
\hline Summated Utilitarian Shopping Motivation Items & 20.690 & 3.076 & - \\
\hline The sales people often assist me to select the dress. & 3.634 & 1.111 & .724 \\
\hline $\begin{array}{l}\text { I enjoy socializing with others (neighbors and co-workers) when I shop for } \\
\text { dress. }\end{array}$ & 3.412 & 1.116 & .506 \\
\hline I go shopping for dress with my family to socialize. & 3.768 & 1.034 & .809 \\
\hline I go shopping for dress with my friends to socialize. & 3.610 & 1.039 & .803 \\
\hline Summated Socialization Shopping Motivation Items & 14.422 & 3.118 & - \\
\hline Clothes. & 3.940 & 1.046 & .840 \\
\hline Shoes. & 3.792 & .978 & .940 \\
\hline Summated Dress Items & 7.732 & 1.900 & - \\
\hline Factor Statistics & Utilitarian & Socialization & Recreational \\
\hline Eigenvalue & 2.915 & 1.741 & 1.533 \\
\hline$\%$ of total Variance $(51.569 \%)$ & 24.288 & 14.510 & 12.771 \\
\hline Average Variance Extracted (AVE) & .425 & .519 & .596 \\
\hline Composite Reliability & .784 & .808 & .801 \\
\hline
\end{tabular}

Concerning the two items of dress information search behavior, the respondents were asked to response to two separate questions "To what extent you consider getting information prior to buying clothes or shoes are very unimportant $=1 \ldots$ very important $=5$ ". Cronbach's alpha (.864), the mean of inter-item correlations (.76), and the squared multiple correlations $>(.50)$ confirmed the convergent validity of construct (Bollen, 1989).

\subsubsection{Model Variables}

Figure 1 displays the relationship between the independent, mediation, and dependent variables. The results of confirmatory factor analysis has revealed that the measures of model's paths manifest a good fit to the observed data $\left(\chi^{2}=56.146, \mathrm{df}=30, \mathrm{CMIN} / \mathrm{DF}=1.872<3, \mathrm{GFI}=.964, \mathrm{AGFI}=.934, \mathrm{NFI}=.914, \mathrm{CFI}=.957, \mathrm{TLI}=.936\right.$, RMSEA $=.055)$. 


\section{Results}

\subsection{Sample Profile}

Results uncovered that males and female were respectively formed $51 \%$ and $49 \%$ of the sample. The information on the marital status has demonstrated that $90 \%$ the respondents are single whereas the rest percentage $(10 \%)$ is related to married respondents. The annual income ranging from 7,000\$ less than $14,000 \$$ formed $40 \%$ of the sample element. The remaining percentage $(60 \%)$ were equally divided into two categories (less than 7,000\$) and $(14,000 \$$ and over). However, the sample characteristics are substantially consonant with the demographic analyzes of Jordanian department of statistics (Jordan Department of Statistics [JDS], 2010).

\subsection{Descriptive Analysis}

Mean scores and standard deviations are presented in Table 1. An overall assessment has demonstrated that there is positive differences between the mean scores that ranged from (3.377) to (4.352) and the midpoint value (3.000) of the subscales items ( $t$ value "mean minus midpoint value" $>2.00, \mathrm{p}=.000)$. Evidently, the highest mean differences were incorporated with utilitrian motives whilst the lowest mean differences were associated with the items of socialization and recreational motives respectively.

\subsection{Testing Hypotheses}

Multiple regression analysis using Structural Equation Modeling and bootstrapping analyzes in AMOS 7 were applied to examine the model's paths. Likewise, the effects of gender and an annual income on the model's variables were tested by the independent-sample $\mathrm{T}$ test and One-Way ANOVA techniques. The bootstrapping test that is relying on a set of $\mathrm{N}$ resampling data (2000-5000) is typically used to measure the mediation effects (Preacher \& Hayes, 2008). It used to avoid the negative impacts resultant from non-normality variables on the research findings (Wood, Goodmann, Beckmann, \& Cook, 2008). As shown in Figure 1, the shopping motives have jointly explained $60 \%$ of consumer self-confidence whilst the consumer self-confidence inclusive shopping motives have interpreted $36 \%$ of dress-information search behavior. In that, utilitarian ( $t$ value $=6.416, \beta=.480$ ), recreational ( $\mathrm{t}$ value $=5.104, \beta=.340$ ), and socialization ( $\mathrm{t}$ value $=4.632, \beta=.320$ ) motives have positively explained the variance of consumer self-confidence at the significance level $(\mathrm{p}=.000)$ suggesting to accept $\mathrm{H} 1$, $\mathrm{H} 5$, and H8. Results also confirmed the direct influences of utilitarian ( $\mathrm{t}$ value $=-4.043, \beta=-.280, \mathrm{p}=.000$ ) and recreational motives ( $\mathrm{t}$ value $=2.632, \beta=.170, \mathrm{p}=.017$ ) on search for dress information, but do not support the influence of socialization motives ( $\mathrm{t}$ value $=-1.480, \beta=-.100, \mathrm{p}=.166$ ). These findings lead to accepting H6 and H9 but do not support H2. Following Baron and Kenny's (1986) suggestions, the partial intervention reflects the significant direct and indirect influences on the criterion variables. The full mediation is ensued when the direct impact of predictor variables on the dependent variables is not significantly observed, and the mediator variable significantly affects the dependent variable. To this end, the results of bootstrapping analyzes have demonstrated that H11, H12, and H13 were significantly supported $(\mathrm{p}=.000)$. Specifically, the consumer self-confidence has partially intervened the effects of utilitarian $(\beta=.310)$ and recreational $(\beta=.223)$ motives on search for dress information behavior whereas the impact of socialization motives $(\beta=.206)$ is fully mediated. Concerning the demographic variables, H10 is entirely rejected owing that to the variability of recreational motives across gender $(\mathrm{t}$ value $=-6.647, \mathrm{df}=282, \mathrm{p}=.000)$ and the annual income $(\mathrm{F}=3.372, \mathrm{df}=2, \mathrm{p}=.036)$. $\mathrm{H} 4$ is partially rejected resultant to the variation of consumer search for dress information across gender ( $t$ value $=-2.908, \mathrm{df}=282, \mathrm{p}=.004)$ but not varied by the annual income $(\mathrm{F}=0.452, \mathrm{df}=2, \mathrm{p}=.637)$ whilst the null hypotheses H7 and H14 are completely accepted (t-values $<2.000, \mathrm{p}>.05$ ). The socialization motives of Jordanian young consumers are differed by the annual income then $\mathrm{H} 3$ is partially rejected.

\section{Discussion}

\subsection{Social Shopping Motivation}

The relationship between consumers' socialization and consumers' motives is documented in the marketing literature (Carlson, Walsh, Lacznick, \& Grossbart, 1994). Results display that young consumer search for dress information is not directly influenced by socialization motives while the socialization motives are positively influenced the self-confidence of Jordanian young consumers. Going to shop with family members, friends, and salespersons' assistance stimulate young consumers to go shopping for a dress. These orientations as mentioned earlier are in agreement with Triandis (2001) and Shoup's (2007) perspectives. In addition, as the age of family member is increased, the more likely friends, salespeople, and media affect his/her consumption behavior (Hyun-Mee \& Miller, 2007; John, 1999; Moschis, 1987). Noticeably, the results are consistent with O'Donnell (2006), Hyun-Mee and Miller (2007), and Davis et al.'s (2012) findings. Female young student college collects 
information from friends, family members, and co-workers respectively when they shopped for apparel purchase (Kinley et al., 2010) to eliminate the risk of unsatisfactory and uncertainty purchases (Barber et al., 2009).

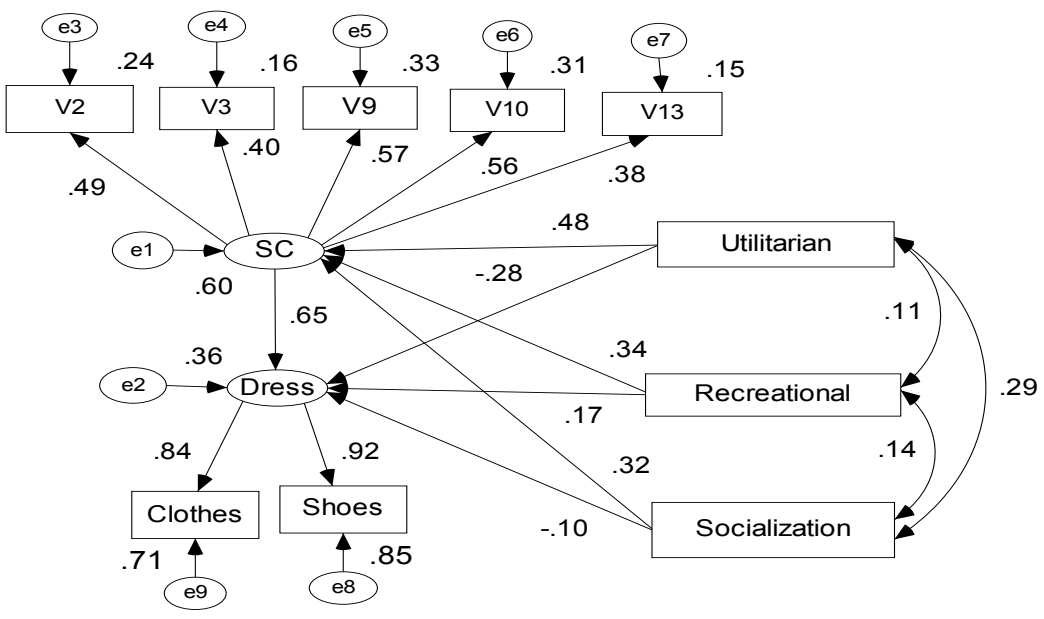

Figure 1. The direct and the indirect influences of shopping motives on dress shopping behavior Notes:SC: Self-confidence; V2,...V13: Self-confidence variables; e1...e9: Varible variance error.

Young consumers rely on friends to avoid the risk of critical errors related to social status (Brusdal, 2002). Moreover, the socialization motives were not varied across gender and an annual income. While these findings are inconsistent with Barber et al.'s (2009) results, the similarity between male and female concerning clothing shopping behavior has been found (Chen-Yu \& Seock, 2002; Dholakia, 1999).

\subsection{Utilitarian Shopping Motivation}

Utilitarian motivation is a unique factor for consumer information search (To, Liao, \& Lin, 2007). Results uncovered that the self-confidence of Jordanian young consumers is positively influenced by utilitarian motives. Utilitarian motives involving competitive offers, a diversity of products, sales prices, and bargaining prices negatively influenced young consumer search for dress information. These results support Bellenger and Korgaonker (1980), Farrag et al. (2010), Mejri et al. (2012) findings as noted previously, but it differed from Paridon's (2006) result; the utilitarian value negatively influences the personal confidence. The adverse influence on search behavior may be accounted for the nature of a product and its characteristics. The product's complexity and categories positively influenced consumer search for information (Fennell, 1978) thus consumer avoids the risks of a wrong decision when it relates to his/her self-image (Solomon et al., 1999). Consequently, it seems that young consumer search for dress information is more related to intangible characteristics of the product (e.g., style, fashion, and country of origin). Moreover, results revealed that utilitarian motives were not differed by gender and an annual income. Workman and Cho (2012) found that both male and female consumers focus on clothing quality and price whereas product price is more important for females than males (Bexley, 2014) who manifest greater utilitarian motives for clothing shopping (Chang et al., 2004).

\subsection{Recreational Shopping Motivation}

Buying clothing is driven by the hedonic values (Hirschman \& Holbrook, 1982) that directly influenced consumer intention to search for information via the Internet (To et al., 2007). Consumers shop to satisfy their intangible values during the shopping trips (Arnold \& Reynolds, 2003). Specifically, enjoyment, leisure activities, and fantasy were respectively constituted the component of recreational motives. These orientations confirmed the positive impact of recreational motives on self-confidence and search for dress information. In this connection, Farrag et al. (2010) and Bakirtas et al.'s (2015) findings as reported previously sustain the research results. Moreover, the results demonstrate that females are more likely to be recreational than males, and the recreational motives differ across the categories of annual income. However, these findings are consonant with Bellenger and Korgaonker (1980), Chen-Yu and Seock (2002), Arnold and Reynolds (2003), and Chang et al.'s (2004) results.

\subsection{Mediation Influence of Self-Confidence}

Broadly speaking, the relationship between self-confidence and consumer behavior is well entrenched in the marketing literature keeping in mind that this relation is differed across individualist and collectivist cultures (Chelminski \& Coulter, 2007). In that, the relative size of effects as reported above was ranged from moderate to 
large following Baron and Kenny's (1986) recommendations. The descriptive analysis sustains the research results, for instance, the lowest score of self-confidence "friends' impression" is positively differed from the midpoint scale at the significance level $<0.05$. Further, the mediation impacts were also consistent with Paridon's (2008) findings. The indirect influence of socialization motives can be ascribed to the ability of young consumers in making purchases decisions competently. If the purchase issue is not resolved through the stored information, the consumer is more likely to seek information from external sources (Solomon et al., 1999) since the high level of one's purchase confidence relies on his/her ability (Barber et al., 2009). Additionally, scholars connected the consumer self-confidence to particular demographic variables in that the consumer self-confidence is not differed by gender and an annual income. These results, however, are contradicted with Bearden et al.'s (2001) findings, but it congruence with Adelmann's (1987) findings relating to gender influence.

\section{Conclusion and Practical Implications}

The results obtained from this study are broadly focused on the dress "clothing and shoes". Dependent on the existing body of literature, the three objectives of this study were accomplished. The construct of shopping motivation was validated within the concept of collectivist values. The unique contribution of the total influence on consumer self-confidence is associated with utilitarian motives followed by recreational motives whilst the recreational motives scored the highest total impacts on searching for dress information. The consumer self-confidence and recreational motives have positively scored the highest direct influences on searching for dress information while the highest intervening influence is connected with utilitarian motives followed by recreational. Furthermore, socialization and utilitarian motives, and self-confidence were not varied across gender and annual income whilst the disagreement between females and males was clearly observed in recreational motives. Consumer search for dress information was only varied by an annual income.

Form strategic perspectives, results draw a number of significant managerial implications for dress retailers. An understanding of consumer shopping motives, consumer self-confidence, and consumer search for dress information is a rudimentary step to designing a blend of efficient marketing strategies to secure consumers' money, efforts, and psychological costs. Consequently, retailers' failure to address these issues competently will gradually urge consumers to buy a dress from other shops because the more satisfied shoppers, the more tendency to repurchase a certain product (Stoel, Wickliffe, \& Lee, 2004). Therefore, dress retailers should adjust their strategies to maintain at least the following aspects:

- Provide clear information about clothing or shoes to substantiate females' predisposition, and to lure males to search for information that including the manufacturer's label, country of origin, and dress features.

- Focus on the direct interactivity with consumer "word of mouth" via selecting qualified and trustworthy salespersons who are courteously and solicitous to consumers need advice but not intrusive in their interactions with customers.

- Focus on real sales prices, true discounts, a fair price-quality relationship, buy one get one free, money-back guarantees, diversity of brands, and fashion style to meet both the self-confidence and the utilitarian motives of young consumers

- Maintain the consumer self-confidence through admiring the consumers shopping experiences and ability.

- Use external environmental cues such as music and lightings, colorful interiors, packaging, and the number of years in clothing or shoes field to attract consumers' attention informatively. The malls' attributes influence both utilitarian and recreational motives (Stoel et al., 2004).

In sum, putting the results of this study and its managerial implications together would create competitive advantages for dress retailers and increase their market share. From the viewpoint of academic research, this study enriches the marketing literature by identifying the role of consumer self-confidence in adjusting the influence of shopping motivation on information search behavior within the context of collectivist culture. Understanding the influence of different consumer socialization in other cultures assists the international marketers to expand their activities globally (Bakir, Rose, \& Shoham, 2006).

\section{Limitation and Future Research}

There are some limitations to this study. The participant responses were not related to specific retail formats, and the consumer self-confidence is not partitioned into high and low levels that may influence its effects on information search behavior and the intervention effects. Likewise, the current study depends on one group aged sample that limit the generalizability of results to the whole population. The low internal consistency of consumer self-confidence needs to be revisited through using a pool of items and then factorized into more than on dimension following Bearden et al.'s (2001) procedures. 
Moreover, future research may examine the same variables on other collectivist cultures such as Asia and Arab countries to assess the convergences and divergences between these countries for better generalization of results. Future research may consider a more specific store formats or products such as wedding dress to measure the differences in intention to search for information under the impacts of shopping motives and consumer self-confidence. Finally, the influence of religion and locus of control could be incorporated into future research since fashion consumer group is determined by the locus of control (Workman \& Studak, 2007).

\section{References}

Adelmann, P. K. (1987). Occupational complexity, control, and personal income: Their relation to psychological well-being in men and women. Journal of Applied Psychology, 72(4), 529-537. http://dx.doi.org/10.1037/0021-9010.72.4.529

Algharabat, R., S., \& Zamil, A. M. (2013). The Impact of Retail Store Global-Mindedness on Jordanian Consumers' Patronage Intention. International Journal of Marketing Studies, 5(4), 30-41. http://dx.doi.org/10.5539/ijms.v5n4p30

Anderson, J. C., \& Gerbing, D. W. (1988). Structural equation modeling in practice: A review and recommended $\begin{array}{llll}\text { Two-Step Approach. } & \text { Psychological 103(3), }\end{array}$ http://dx.doi.org/10.1037/0033-2909.103.3.411

Arnold, M. J., \& Reynolds, K. E. (2003). Hedonic shopping motivations. Journal of Retailing, 79(2), 77-95. http://dx.doi.org/10.1016/S0022-4359(03)00007-1

Babin, B., Darden, W., \& Griffin, M. (1994). Work and/or fun: measuring hedonic and utilitarian shopping value. Journal of Consumer Research, 20(4), 644-656. http://dx.doi.org/10.1086/209376

Bagozzi, R. P., \& Yi, Y. (1988). On the evaluation of structural equation models. Journal of the Academy of Marketing Science, 16(1), 74-94. http://dx.doi.org/10.1007/BF02723327

Bakir, A., Rose, G. M. and Shoham, A. (2006). Family communication patterns: mothers' and fathers' communication style and children's perceived influence in family decision making. Journal of International Consumer Marketing, 19(2), 75-95. http://dx.doi.org/10.1300/J046v19n02_05

Bakirtas, H., Bakirtas, I., \& Cetin, M. A. (2015). Effects of utilitarian and hedonic shopping value and consumer satisfaction on consumer behavioral intentions. Ege Academic Review, 15(1), 91-98.

Barber. N., Dodd, T., \& Kolyesnikova, N. (2009). Gender differences in information search: implications for retailing. Journal of Consumer Marketing, 26(6), 415-426. http://dx.doi.org/10.1108/07363760910988238

Baron, R. M., \& Kenny, D. A. (1986). The moderator-mediator variable distinction in social psychological research: Conceptual, strategic and statistical considerations. Journal of Personality and Social Psychology, 51(6), 1173-1182. http://dx.doi.org/10.1037/0022-3514.51.6.1173

Bearden, W. O., Hardesty, D. M., \& Rose, R. L. (2001). Consumer self-confidence: Refinements in conceptualisation and measurement. Journal of Consumer Research, 28(June), 121-134. http://www.jstor.org/stable/10.1086/321951

Bellenger, D. N., \& Korgaonkar, P. K. (1980). Profiling the recreational shopper, Journal of Retailing, 56(3), 77-92.

Bennet, P. D., \& Harrell, G. D. (1975). The role of confidence in understanding and predicting buyers' attitudes and purchase intentions. Journal of Consumer Research, 2(Sep.), 110-117. http://dx.doi.org/10.1086/208622

Bexley, J. B. (2014). Do celebrities influence buying habits? Journal of Management and Marketing Research, 17(October), 1-9.

Bollen, K. A. (1989). Structural equations with latent variables. New York: John Wiley and Sons.

Brucks, M. (1985). The effects of product class knowledge on information search behavior. Journal of Consumer Research, 12(June), 1-16. http://dx.doi.org/10.1086/209031

Brusdal, R. (2002). Identity work at the shopping mall. Tidsskrift for Ungdomsforskning, 4(1), 12-17.

Buttle, F. (1992). Shopping motives constructionist perspective. The Services Industries Journal, 12(3), 349-368. http://dx.doi.org/10.1080/02642069200000044 
Cai, Y., \& Shannon, R. (2012). Personal values and mall shopping behaviour the mediating role of intention among Chinese consumers. International Journal of Retail and Distribution Management, 40(4), 290-317. http://dx.doi.org/10.1108/09590551211211783

Cal B., \& Adams, R. (2014). The effect of hedonistic and utilitarian consumer behavior on brand equity: Turkey-UK comparison on Coca Cola. Procedia Social and Behavioral Sciences, (150), 475-484. http://dx.doi.org/10.1016/j.sbspro.2014.09.057

Carlson, L., Walsh, A., Lacznick, R. and Grossbart, S. (1994). Family communication patterns and marketplace motivations, attitudes, and behaviours of children, and mothers. Journal of Consumer Affairs, 28(1), 25-54. http://dx.doi.org/10.1111/j.1745-6606.1994.tb00813.x

Chang, E., Burns, L. D., \& Francis, S. K. (2004). Gender differences in the dimensional structure of apparel shopping satisfaction among Korean consumers: The role of hedonic shopping value. Clothing and Textiles Research Journal, 22(4), 185-199. http://dx.doi.org/10.1177/0887302X0402200404

Chelminski, P., \& Coulter, R.A. (2007). On market mavens and consumer self-confidence: A cross-cultural study. Psychology \& Marketing, 24(1), 69-91. http://dx.doi.org/10.1002/mar.20153

Chen-Yu, J. H., \& Seock, Y. K. (2002). Adolescents' clothing purchase motivations, information sources, and store selection criteria: a comparison of male/female and impulse/nonimpulse shoppers. Family and Consumer Sciences Research Journal, 31(1), 50-77. http://dx.doi.org/10.1177/1077727X02031001003

Churchill G.A., Jr. (1979). A paradigm for developing better measures of marketing constructs. Journal of Marketing Research, 16(February), 64-73. http://dx.doi.org/10.2307/3150876

Damhorst, M. L., Miller, K. A., \& Michelman, S. (2005). Meanings of Dress (2nd ed.). New York: Fairchild Publications.

Danesi, M. (2004). Messages, signs, and meanings: A basic textbook in semiotics and communication theory (2nd ed). Toronto: Canadian Scholars' Press.

Davis, L., Peyrefitte, J., \& Hodges, N. (2012). From motivation to store choice: Exploring northwest Chinese consumers' shopping behavior. International Journal of China Marketing, 3(1), 71-87.

Dawson, S., Bloch, P. H., \& Ridgway, N. M. (1990). Shopping motives, emotional states, and retail outcomes. Journal of Retailing, 66(4), 408-427.

Dholakia, R. R. (1999). Going shopping: key determinants of shopping behaviors and motivations. International Journal of Retail and Distribution Management, 27(4), 154-165. http://dx.doi.org/10.1108/09590559910268499

Farrag, D. A., El Sayed, I. M., \& Belk, R.W. (2010). Mall shopping motives and activities: A multimethod approach. Journal of International Consumer Marketing, 22(2), 95-115. http://dx.doi.org/10.1080/08961530903476113

Feinberg, R. A., Sheffler, B., Meoli, J., \& Rummel, A. (1989). There's something social happening at the mall. Journal of Business and Psychology, 4(1), 49-63. http://dx.doi.org/10.1007/BF01023038

Fennell, G. (1978). Consumers' perceptions of the product-use situation. Journal of Marketing, 42(April), 38-47. http://dx.doi.org/10.2307/1249884

Geuens, M., Brengman, M. S., \& Jegers, R. (2001). An exploratory study of grocery shopping motivations. European Advances in Consumer Research, 5, 135-140.

Guiry, M., Magi, A. W., \& Lutz, R. J. (2006). Defining and measuring recreational shopper identity. Journal of the Academy of Marketing Science, 34(1), 74-83. http://dx.doi.org/10.1177/0092070305282042

Hair, J. F., Black, B., Babin, B., \& Tatham, R. (2006). Multivariate Data Analysis (6th ed.). Upper Saddle River, NJ: Prentice Hall.

Hatcher, L. (1994). A step-by-step approach to using the SAS(R) System for factor analysis and structural equation modeling. Cary, NC: SAS Institute Inc.

Hellén, K., \& Sääksjärvi, M. (2011). Is consumer self-confidence a stable phenomenon? the effect of mood on self-confidence dimensions. Journal of Customer Behaviour, 10(3), 223-243. http://dx.doi.org/10.1362/U7539211X602496

Hirschman, E. C., \& Holbrook, M. B. (1982). Hedonic consumption: emerging concepts, methods, and propositions. Journal of Marketing, 46(1), 92-101. http://dx.doi.org/10.2307/1251707 
Howard, J. A., \& Sheth, J. N. (1969). The theory of buyer behavior. NY: John Wiley and Sons, Inc.

Hyun-Mee, J., \& Miller, N. J. (2007). Examining the effects of fashion activities on life satisfaction of older females: Activity theory revisited. Family and Consumer Sciences Research Journal, 35(4), 338-356. http://dx.doi.org/10.1177/1077727X07299992

Jin, B., \& Kim, J. (2003). A typology of Korean discount shoppers: shopping motives, store attributes, and outcomes. International Journal of Service Industry Management, 14(4), 396-419. http://dx.doi.org/10.1108/09564230310489240

Jin, B., Sternquist, B., \& Koh, R. (2003). Price as hedonic shopping. Family and Consumer Sciences Research Journal, 31(4), 378-402. http://dx.doi.org/10.1177/1077727X03031004003

John, D. R. (1999). Consumer socialization of children: a retrospective look at twenty-five years of research. Journal of Consumer Research, 26(3), 183-213. http://dx.doi.org/10.1086/209559

Jordan Department of Statistics. (2010). Retrieved from http://web.dos.gov.jo/?lang=ar

Kalliny, M, Saran, A., Ghanem, S., \& Fisher, C. (2011). Cultural differences and similarities in television commercials in the Arab World and the United States. Journal of Global Marketing, 24(1), 41-57. http://dx.doi.org/10.1080/08911762.2011.545719

Kinley, T., Josiam, B., \& Lockett, F. (2010). Shopping behavior and the involvement construct. Journal of Fashion Marketing and Management, 14(4), 562-575. http://dx.doi.org/10.1108/13612021011081742

Lim, E. A., \& Ang, S. H. (2008), Hedonic vs. utilitarian consumption: A cross-cultural perspective based on cultural conditioning. Journal of Business Research, 61(3), 225-232. http://dx.doi.org/10.1016/j.jbusres.2007.06.004

Lysonski, S., \& Durvasula, S. (2013). Consumer decision making styles in retailing: Evolution of mindsets and psychological impacts. Journal of Consumer Marketing, 30(1), 75-87. http://dx.doi.org/10.1108/07363761311290858

MacCallum, R. C., Browne, M. W., \& Sugawara, H. M. (1996). Power analysis and determination of sample size for covariance structure modeling. Psychological Methods, 1(2), 130-149. http://dx.doi.org/10.1037/1082-989X.1.2.130

Mejri, M., Debabi M., \& Nasraoui K. (2012). Exploratory analysis of the shopping orientation in the Tunisian context. International Journal of Marketing Studies, 4(5), 1-13. http://dx.doi.org/10.5539/ijms.v4n5p1

Minahan S., \& Huddleston P. (2010). Shopping with mum -mother and daughter consumer socialization. Young Consumers, 11(3), 170-177. http://dx.doi.org/10.1108/17473611011074241

Moore, E. S., Wilkie, W. L., \& Lutz, R. J. (2002). Passing the torch: IGI as a source of brand equity. Journal of Marketing, 66(April), 17-37. http://dx.doi.org/10.1509/jmkg.66.2.17.18480

Moschis, G. (1987). Consumer socialization: a life style perspective. Lexington, MA: Lexington Books.

O'Donnell, J. (2006). Gen Y sits on top of consumer food chain: they're savvy shoppers with money and influence. USA Today (Arlington, VA), October 11, 3B.

Paridon, T. J. (2006). Extending and clarifying causal relationships in research involving retailing practices, personal shopping value, consumer self-confidence, and word of mouth communication. The Marketing Management Journal, 16(1), 32-43.

Paridon, T.J. (2008). Consumer Self-Confidence and Patronage Intensity heuristics in shopping focused word of mouth communication. The Marketing Management Journal, 18(1), 84-99.

Park, C., Mothersbaugh, D., \& Feick, L. (1994). Consumer knowledge assessment. Journal of Consumer Research, 21(1), 71-82. http://dx.doi.org/10.1086/209383

Preacher, K. J., \& Hayes, A. F. (2008). Asymptotic and resampling strategies for assessing and comparing indirect Effects in multiple mediator models. Behavior Research Methods, 40(3), 879-891. http://dx.doi.org/10.3758/BRM.40.3.879

Sheth, J. N. (1983). An integrative theory of patronage preference and behavior. In W. R. Darden \& R. F. Lusch (Eds.), Patronage behavior and retail management (pp. 9-28). New York, NY: North-Holland. 
Shim, S., \& Kotsiopulos, A. (1992). Patronage behavior of apparel shopping: Part II. Testing a patronage model of consumer behavior. Clothing and Textile Research Journal, 10(2), 58-64. http://dx.doi.org/10.1177/0887302X9201000209

Shoup, J. A. (2007). Culture and customs of Jordan (1st ed.). USA: Greenwood Press.

Solomon, M., Bamossy, G., \& Askegaard, S. (1999). Consumer behaviour A European perspective (4th ed.). Pearson education limited.

Stoel, L., Wickliffe, V., \& Lee, K. H. (2004). Attribute beliefs and spending as antecedents to shopping value. Journal of Business Research, 57(10), 1067-1073. http://dx.doi.org/10.1016/S0148-2963(03)00016-X

Tauber, E. M. (1972). Why do people shop? Journal of Marketing, 36, 46-59. http://dx.doi.org/10.2307/1250426

Teichmann, K. (2011). Expertise, experience and self-confidence in consumers' travel information search. International Journal of Culture, Tourism and Hospitality Research, 5(2), 184-194. http://dx.doi.org/10.1108/17506181111139591

To, P. L., Liao, C., \& Lin, T. H. (2007). Shopping Motivations on Internet: A Study Based on Utilitarian and Hedonic Value. Technovation, 27(12), 774-787. http://dx.doi.org/10.1016/j.technovation.2007.01.001

Triandis, H. C. (2001). Individualism-collectivism and personality. Journal of Personality, 69(6), 907-924. http://dx.doi.org/10.1111/1467-6494.696169

Tsao, W., \& Tsao, W-Y. (2013). Importance for assurance from transparent windows: A dual motivation

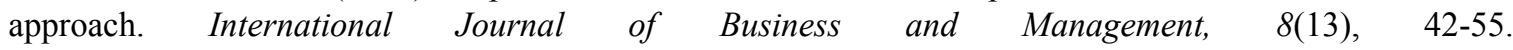
http://dx.doi.org/10.5539/ijbm.v8n13p42

Westbrook, R. A., \& Black, W.C. (1985). A motivation-based shopper typology. Journal of Retailing, 61(3), 78-103.

Wood, R., Goodmann, J. S., Beckmann, N., \& Cook, A. (2008). Mediation testing in management research: A review and proposals. Organizational Research Methods, 11(2), 270-295. http://dx.doi.org/10.1177/1094428106297811

Workman, J. E., \& Cho, S. (2012). Gender, fashion consumer groups, and shopping Orientation. Family \& Consumer Sciences Research Journal, 40(3), 267-283. http://dx.doi.org/10.1111/j.1552-3934.2011.02110.x

Workman, J. E., \& Studak, C. M. (2007). Relationships among fashion consumer groups, locus of control, boredom proneness, boredom coping and intrinsic enjoyment. International Journal of Consumer Studies, 31(1), 66-75. http://dx.doi.org/10.1111/j.1470-6431.2005.00486.x

\section{Copyrights}

Copyright for this article is retained by the author(s), with first publication rights granted to the journal.

This is an open-access article distributed under the terms and conditions of the Creative Commons Attribution license (http://creativecommons.org/licenses/by/3.0/). 